\title{
SOME PHYSIOLOGICAL REACTIONS OF NEW ZELAND RABBIT TO DRINKING WATER POLLUTED BY THE INSECTICIDE "PROFENOFOS"
}

\author{
S. M. Salem ${ }^{1}$ and M.I.Kobeasy ${ }^{2}$ \\ 1- Department of Animal Production, Faculty of Agriculture, Cairo University, \\ Giza, Egypt, 2- Department of Biochemistry, Faculty of Agriculture, Cairo \\ University, Giza, Egypt
}

\section{SUMMARY}

The present investigation was carried out on New Zealand rabbits to determine the physiological reactions through liver, kidney, and thyroid functions and relevant blood compounds with the polluted water by 75 and 150 ppm of the insecticide Profenofos. The animals were exposed to the polluted water drinking for 60 days. Blood samples were collected at 30 and 60 days. Male rabbit given sub-lethal doses of 75ppm and 150ppm profenofos in drinking water showed a significant increase in the red blood cells count (RBCs), haemoglobin concentration (Hb) and packed cell volume (PCV) at 150ppm of profenofos after 60 days $(116.6 \%$ \& $110.6 \%, 109.8 \%$ \& $114 \%$ and $116.7 \%$ \& $112 \%$ respectively), a significant elevation in the mean corpuscular volume (MCV) was noted at the highest concentration (150ppm) after 30 days, whereas a significant decrease occurred in the values of mean corpuscular haemoglobin concentration (MCHC) after 60 days, (75.3\% and 87.7\% respectively). A significant decrease in the total white blood cells (leukopemia) was observed in treated rabbit. There was an elevation in (ALT) activity after 60 days and the increased values was $124.3 \%$ for $150 \mathrm{ppm}$ relative to control, also a decreases in concentration of albumin ( $A L B)$ was observed. The Profenofos caused inhibition of cholinesterase activity almost at all the treatment periods. There was not any marked change in cholesterol concentration throughout the experimental period (60 days).Also the level of the urea in treated rabbits decreased after 30 days of treatment with tested concentration $43.7 \%$ \& 34.2\% for 75 and 150 ppm respectively. The creatinine concentration decreased significantly after 60 day from treatment with high treatment (150 ppm).

Keywords: Profenofos insecticide, polluted water, liver, kidney, thyroid functions, hematology

\section{INTRODUCTION}

As the demand for agricultural products increases, so inevitably does the need for pesticides. Currently organophosphorus compounds are part of a large group of

Issued by The Egyptian Society of Animal Production 
synthetic pesticides that have been developed in the last 50 years, and are commonly used in agricultural and public health. Due to their wide use, contamination of food, water, and air has become imminent and consequently adverse heath effects are inevitable in humans, animals, wildlife and fish (Gupta, 1994). The use of pesticides not only increased the crop yields but also helped in controlling ectoparasites on livestock. However, widespread use of these chemicals is not without risks. There have been several instances of poisoning in animals. Animals get exposed to these pesticides due to accidental ingestion due to their inadvertent use for the control of ectoparasites and insects in the vicinity of poultry, rabbit, and animal houses. Residues of the grain protectant pesticides may also come in animal feeds. Perusal of literature did not reveal the toxicity of "Profenofos" insecticide on rabbit in Egypt.

The aim of this study is to determine the effect of polluted water by profenofos on liver; kidney and thyroid gland functions and on the changes in relevant blood compounds as physiological reactions in male New Zealand rabbits as farm animals.

\section{MATERIALS AND METHODS}

\section{Experimental animals:}

New Zealand rabbits weighing $2.4 \pm 0.3 \mathrm{~kg}$ were supplied by the farm of General Organization of Serum and Vaccine (Helwan farm). The present studies were preformed on 30 mature male New Zealand rabbits. The animals were allowed to acclimatize to laboratory conditions for a period of 3 weeks prior to the experiment. The animals were kept on balanced diet throughout the experimental period. Feed and water were available ad lib during the experiment.

\section{Experimental design:}

Randomized groups, of these rabbits housed in cages, were allocated into three treatment groups, (10 each) and treated with Profenofos through drinking water for 60 successive days. The animals groups were as follow: group (A) rabbits kept without any treatment (as a control), and Groups (B) and (C) rabbits treated with Profenofos in drinking water at 75 and 150 ppm, respectively. On day 30 and 60, blood samples were taken from each rabbit.

\section{Blood samples:}

Blood samples were collected from Occuseal veins by heparinized capillary tubes at into clean, dry and labeled eppendorf of tubes $(1.5 \mathrm{ml})$. Each blood sample was divided into two aliquots, one containing EDTA (Ethylenediamine tetra acetic acid) as anticoagulant (1mg/ml blood) for studying the hemogram of the experimental animals, the second aliquot was left at room temperature for 2 hours before centrifugation at $3500 \mathrm{rpm}$. for 15 minutes in a refrigerated centrifuge to separate serum, and kept in a deep freezer at $\left(-20^{\circ} \mathrm{C}\right)$. Serum samples were examined for studied parameters. Counts of red and white blood cells, hemoglobin concentration, and packed cell volume were determined according to the methods of Schalm (1986). The erythrocytes indices; mean corpuscular volume (MCV), mean corpuscular haemoglobin $(\mathrm{MCH})$ and mean corpuscular haemoglobin concentration (MCHC) were also calculated depending on RBCs count, haemoglobin concentrations $(\mathrm{Hb})$ and packed cell volume $(\mathrm{PCV})$ as follow:

\section{MCV $=\{$ PCV (vol \%) $/$ RBCs $($ million $/ \mathrm{ml})\}$ X $10=$ F1}


$\mathrm{MCH}=\{\mathrm{Hb}(\mathrm{g} / \mathbf{1 0 0 m l}) / \mathrm{RBCs}($ million $/ \mathrm{ml})\} \times 10=\mathrm{Pg}$

MCHC $=\{\mathbf{H b}(\mathrm{g} / \mathbf{1 0 0 m l}) /$ PCV $($ vol. \%) $\}$ X $100=\%$

Thyroxin $\left(\mathrm{T}_{4}\right)$, and Tri-iodothyronine $\left(\mathrm{T}_{3}\right)$ were determined in serum according to Britton et al. (1975) by the coat -A- count technique, using kits purchased from Diagnostic Products Corporation (DPC).

The following physiological parameters expressed the liver function:

The activities of alanine aminotransferase (ALT) and aspartate aminotransferase (AST) were determined spectrophotometrically according to Reitman and Frankel (1957). Serum total protein concentration (T.P g/dl) was determined spectrophotometrically according to Henry et al. (1974). Serum albumin concentration (ALB g/dl) was determined spectrophotometrically by the method of Bartholomew and Delaney (1964).Alkaline phosphatase activity (ALP U/1) was colorimetricaly estimated according to the method of Empfehlungen (1972). The activity of cholinesterase (ChE) was determined kinetically according to the method Waber et al. (1966). Serum cholesterol concentration was determined spectrophotometrically by the method adopted by Siest et al. (1981).

The following physiological parameters are expressed the kidney function: Serum urea concentration $(\mathrm{g} / \mathrm{dl})$ was measured spectrophotometrically by the method of Patton and Crouch (1977). Serum creatinine (mg/dl) was measured spectrophotometrically by the method of Faulkner and King (1976).

\section{Statistical analysis}

Data were subjected to statistical analysis by least squares analysis of variance $2 \times 2$ factorial design. The main effects of treatment and duration and all possible interaction terms were included in the model according to the procedures reported by Snedecor and Cochran (1980); and " $t$ " test was performed to evaluate the difference between mean values of the treated groups and those of the control group.

\section{RESULTS AND DISCUSSION}

Effects of Profenofos on haematological parameters and $\mathrm{T}_{3}$ and $\mathrm{T}_{4}$ of rabbits are shown in Table (1). Male rabbits given sub-lethal doses of $75 \mathrm{ppm}$ and $150 \mathrm{ppm}$ Profenofos in drinking water showed a significant increase in the red blood cells count (RBCs), haemoglobin concentration $(\mathrm{Hb})$ and packed cell volume (PCV), being significant at $150 \mathrm{ppm}$. The percentage increases by $150 \mathrm{ppm}$ after30 and 60 days were $(16.6 \% \& 17.6 \% \& 5.8 \%$ and $15 \% ; 17.7 \% \& 13 \%$ respectively). The exposures of rabbit to both doses of Profenofos lead to a significant decrease in the white blood cells (WBCs) after 30 days the decrease with percentages of $21.3 \%$ for $75 \mathrm{ppm}$ and $11.5 \%$ for $150 \mathrm{ppm}$ relative to control. But WBCs increased significantly after 60 days for $150 \mathrm{ppm}$. In the present study, a significant elevation in the mean corpuscular volume (MCV) was noted by the highest treatment (150ppm) after 30 days. It is clear that the level of MCV after 60 days was lower than after 30 days, and the differences between $\mathrm{MCV}$ values at $75 \mathrm{ppm}$ and $150 \mathrm{ppm}$ were not significant. However a significant decrease in the values of mean corpuscular haemoglobin $(\mathrm{MCH})$ and mean corpuscular haemoglobin concentration (MCHC) were recorded after 60 days, $(75.3 \%$ and $87.7 \%$ respectively). 
Table 1. Effect of Profenofos treatments on haemogram parameters in male New Zealand rabbit

\begin{tabular}{|c|c|c|c|c|c|c|}
\hline \multirow{2}{*}{$\begin{array}{l}\text { Dose } \\
\text { Parameters }\end{array}$} & \multicolumn{3}{|c|}{ after 30 (days) } & \multicolumn{3}{|c|}{ after 60 (days) } \\
\hline & Control & $75 \mathrm{ppm}$ & $150 \mathrm{ppm}$ & Control & $75 \mathrm{ppm}$ & 150 ppm \\
\hline $\mathrm{RBCs} \times 10^{6} \quad \mu \mathrm{l}$ & $6.90 \pm 0.1$ & $7.00 \pm 0.27$ & $8.11 \pm 0.23 *$ & $7.18 \pm 0.12$ & $7.86 \pm 0.25$ & $8.43 \pm 0.09 * *$ \\
\hline $\mathrm{WBC} \times 10^{3} \quad \mu 1$ & $6.1 \pm 0.71$ & $4.5 \pm 0.36^{*}$ & $5.40 \pm 0.33 *$ & $7.4 \pm 0.73$ & $6.76 \pm 0.17$ & $9.12+0.85^{*}$ \\
\hline $\mathrm{Hb} \mathrm{g} / \mathrm{dl}$ & $16.11+1.24$ & $18 . \overline{8}+1.06$ & $17.02 \pm 1.15^{*}$ & $16 . \overline{9} 0 \pm 0.34$ & $15.0 \overline{1}+0.32$ & $19.4 \overline{3} \pm 0.16^{* *}$ \\
\hline $\operatorname{PCV}(\%)$ & $51.5 \pm 2.63$ & $52.5 \pm 1.32$ & $64.33 \pm 0.48 * *$ & $51.00 \pm 0.83$ & $55.00 \pm 0.63$ & $58.7 \pm 1.42 * *$ \\
\hline MCV Fl & $70.4 \pm 2.8$ & $75.9 \overline{6} \pm 2.4$ & $90.6 \pm 0.9 * *$ & $66.49 \pm 0.23$ & $68.05 \pm 3.1$ & $70.4 \overline{6} \pm 2.5$ \\
\hline $\mathrm{MCH} \quad \mathrm{Pg}$ & $21.20 \pm 1.1$ & $19.81 \pm 0.33$ & $22.6 \overline{1} \pm 3.19$ & $20.37 \pm 0.79$ & $23.53 \pm 1.01$ & $18.88 \pm 0.34 *$ \\
\hline $\mathrm{MCHC} \%)$ & $33.4 \pm \overline{3} .33$ & $28.02 \pm 2.0$ & $29.31 \pm 1.94$ & $32.9 \pm 0.7$ & $29.04 \pm 0.6 * *$ & $25.7 \pm 2.05^{*}$ \\
\hline $\mathrm{T}_{4} \mathrm{n} \mathrm{mol} / 1$ & $68.00 \pm 2.7$ & $62.55 \pm 1.2$ & $65.38 \pm 5.55$ & $75.5 \pm 3.74$ & $60.32 \pm 6.31$ & $54.49 \pm 3.35^{* *}$ \\
\hline $\mathrm{T}_{3} \mathrm{n} \mathrm{mol} / \mathrm{l}$ & $1.133 \pm 0.1$ & $1.32 \pm 0.03$ & $1.523 \pm 0.1$ & $0.825 \pm 0.12$ & $1.24 \pm 0.07 *$ & $11.95 \pm 0.17^{*}$ \\
\hline
\end{tabular}

Sub-chronic toxicity by these Profenofos treatment induced erythrocytosis in male rabbits after dosing with 150ppm for 60 days as well as an elevation in the PCV values, this condition referred to absolute polycythemia, which may be caused by hypoxia in treated animals meanwhile, a significant increase in the PCV values in the $150 \mathrm{ppm}$ group after 60 days may be attributed to dehydration in the Profenofos, treated rabbits. This data are in accordance with those reported by Jain (1993).

A significant decrease in the total white blood cells (leukopemia) observed in treated rabbit may be attributed to lymphopemia resulting from release of stress hormone (corticosteroids) in treated rabbits as suggested by Marx (1996). The results in Table (1) indicate that male rabbits treated with profenofos showed a significant decrease in the concentration of thyroxin $\left(T_{4}\right)$ and Tri-iodothyronine $\left(T_{3}\right)$ (hypothyrodism) after 30 days of treatment by 150 ppm and after 60 days by both 75 ppm and $150 \mathrm{ppm}$. The results of this present work are in agreement with those found by Abd Ellah (1987), Farid (1997), Hotz et al. (1997), and Salem et al. (1999). They stated that, a significant decrease of $\mathrm{T}_{4}$ and $\mathrm{T}_{3}$ occurred after administration of different pesticides to experimental animals.

Data in Table (2) illustrates that treatment of male New Zealand rabbits with Profenofos resulted in elevation in (ALT) activity after 60 days and the increased values was $24.3 \%$ for $150 \mathrm{ppm}$ relative to control, although the enzyme activity was decreased significantly (74\%) after 30 days of treatment for the concentration 75 ppm., El-Said (1997) and El-Halwagy (2000, mentioned that ALT and AST did not alter significantly after treatment with Diniconazole and Monocrotophos at all tested dose for 90 days in rats. Hashem (1980) reported that the depression in the activity of transaminases might be due to the formation of complex compounds with ALT or AST in the liver. Aspartate aminotransferase (AST) and alanine aminotransferase (ALT) have long been used as sensitive indicators of liver disease in animals and have been regarded as being virtually liver specific (Wills 1985).

The data in table (2) shows that there is not change in total protein (TP) concentration throughout the experimental period. It should be mentioned that the present data are in a quite good agreement with those reported by El-Kashoury (1999) and Hassan et al. (2002) who reported that total protein concentration changed insignificantly in experimental animals exposed to Dimethoate (OP), Oxamyl (carbamat insecticide), Malathion, Fenitrothion and mixture of some synthetic pecticides (Imidacloprid, Profenofos, and Carbosulfan). On the other hand; Zidan et 
al. (1998) and Choudhary \& Joshi (2002) reported increase in total protein concentration by treatment with some synthetic pesticide .

Table 2. Effect of Profenofos on liver and kidney functions of male New Zealand Rabbit

\begin{tabular}{|c|c|c|c|c|c|c|}
\hline \multirow{2}{*}{$\begin{array}{l}\text { Dose } \\
\text { Parameters }\end{array}$} & \multicolumn{3}{|c|}{ after 30 (days) } & \multicolumn{3}{|c|}{ after 60 (days) } \\
\hline & Control & $75 \mathrm{ppm}$ & 150 ppm & Control & $75 \mathrm{ppm}$ & 150 ppm \\
\hline ALT U/ml & $176 \pm 11.0$ & $170 \pm 13.0^{*}$ & $130.2 \pm 23.2$ & $180.6 \pm 23.9$ & $190 \pm 12.5$ & $223.7 \pm 6.0^{*}$ \\
\hline AST U/ml & $153 \pm 21.5$ & $136.2 \pm 4.2$ & $127 \pm 24.2$ & $184 \pm 23.9$ & $194.7 \pm 2.7$ & $177.3 \pm 6.6$ \\
\hline T.P g/dl & $6.44 \pm 0.7$ & $8.135 \pm 0.9$ & $7.675 \pm 0.8$ & $6.263 \pm 0.5$ & $6.591 \pm 0.6$ & $6.55 \pm 6.8$ \\
\hline ALB $\mathrm{g} / \mathrm{dl}$ & $3.684 \pm 0.1$ & $4.026 \pm 0.25$ & $3.655 \pm 0.1$ & $4.51 \pm 0.1$ & $3.721 \pm 0.4$ & $3.46 \pm 0.1 * *$ \\
\hline ALP U/1 & $60.42 \pm 3.41$ & $51.79 \pm 5.3$ & $37.06 \pm 4.98 * *$ & $68.02 \pm 13.14$ & $65.6 \pm 7.8$ & $34.1 \pm 6.36^{* *}$ \\
\hline $\mathrm{ChE}$ & $600.6 \pm 41.6$ & $480.3 \pm 67.4$ & $350.3 \pm 43.64 *$ & $580.77 \pm 35.19$ & $397.3 \pm 17.4^{*}$ & $444.46 \pm 48.9^{*}$ \\
\hline $\begin{array}{l}\text { Cholesterol } \\
\mathrm{mg} / \mathrm{dl}\end{array}$ & $0.713 \pm 0.44$ & $0.714 \pm 0.10$ & $0.64 \pm 0.08$ & $0.647 \pm 0.06$ & $0.665 \pm 0.1$ & $0.57 \pm 0.185$ \\
\hline Urea $\mathrm{g} / \mathrm{dl}$ & $0.173 \pm 0.06$ & $0.097 \pm 0.04$ & $0.114 \pm 0.05 * *$ & $0.181 \pm 0.05$ & $0.079 \pm 0.1$ & $0.099 \pm 0.06 * *$ \\
\hline $\begin{array}{l}\text { Creatinine } \\
\mathrm{mg} / \mathrm{dl}\end{array}$ & $1.675 \pm 0.22$ & $0.324 \pm 0.12^{* *}$ & $0.268 \pm 0.04 * *$ & $1.701 \pm 0.06$ & $0.651 \pm 0.09 * *$ & $0.548 \pm 0.04 * *$ \\
\hline
\end{tabular}

Data in Table (2) illustrates that; the Profenofos induced significant decrease in concentration of albumin (ALB) after 60 days of treatment with high dose of $(76.8 \%$ for $150 \mathrm{ppm})$. The present results are generally similar to those reported by several workers. Ayyat (2000) and Ahmed et al. (2002), who mentioned that total albumin, was altered significantly according to the type of different pesticides.

Data in Table (2) reveal that Profenofos induced significant decreases in activity of alkaline Phosphates (ALP) after 30 and 60 days of treatment under high concentration of profenofos where values of ALP activities reached $45.5 \%$ and $51.9 \%$, respectively compared with control. These results were supported by the degenerative changes and necrotic change observed in the liver by the histopathological examination. The present results are in agreement with those reported by El-Kashoury (1999). Who reported that, rats exposed to formulated mixture of three organophosphorus pesticides showed a significant decrease in ALP activities. Hassan et al. (2002) reported that plasma alkaline phosphatase (ALP) did not alter throughout the experimental period (60 days) at $500 \mathrm{mg} / \mathrm{kg} \mathrm{Bwt} \mathrm{of}$ Fenitrothion (OP) in treated New Zealand male rabbits.

The present results revealed that Profenofos caused inhibition of cholinesterase activity almost at the two periods. The results are in agreement with those obtained by Ahmed et al. (2002), Zayed et al. (2003), Rahman \& Siddiqui (2003) and Maryam Akhgari et al. (2003), they mentioned that, ChE activity was decreased significantly in the experimental animals after exposeure to organophosphorus compounds.

The results in Table (2) revealed that Profenofos administrated to male New Zealand Rabbits at the two tested concentrations did not cause any marked changes in cholesterol concentration throughout the experimental period (60 days).

In mammals, the kidney functions as a major excretory organ for elimination of metabolic wastes from the body. In most species, death occurs within a week after total cessation of renal function. Urea is biosynthesized in the liver from ammonia. Data presented in table (2) reveale a decrease in the level of the urea in treated rabbits after 30 days of treatment by $43.7 \%$ \& $34.2 \%$ for 75 and $150 \mathrm{ppm}$, respectively. The 
results are in agreement with those recorded by El Kashoury (1999) who observed that urea concentration was decreased significantly in Imidaclopride, Profenofos and Carbosulfan mixture treated rats.

Creatinine is a waste product derived from creatine and creatine phosphate. It is clear from data (Table 2) that creatinine decreased significantly after 60 day by treatment with $150 \mathrm{ppm}$. Values of creatinine concentration reached $39 \%$ relative to control. The present results are in accordance with those reported by El-Said (1997). They found that creatinine concentration was decreased in experimental animals administered with synthetic pesticides.

\section{CONCLUSION}

The studied criteria included: relevant blood traits as well as, liver, kidney and thyroid functions. The male New Zealand rabbit were treated with Profenofos through drinking water for 60 days with two concentrations (75 and $150 \mathrm{ppm}$ ). Profenofos reduced ALT, Cholinesterase (ChE) and alkaline phosphates activities after 30 days at low and high concentrations ( $75 \mathrm{ppm}$ and $150-\mathrm{ppm})$. no significant changes appeared after 30 and 60 days in AST activity and in cholesterol and TP concentrations. Albumin (ALB) concentration decreased in rabbits treated by 150 ppm after 60 days. But, the highest concentration $(150 \mathrm{ppm})$ showed significant increase in albumin content after 60 days of treatment. Urea and Creatinine concentrations were decreased significantly by 75 and 150 ppm for 30 days. Profenofos induced a significant increase in the level of $T_{3}$ and $T_{4}$ after 60 days at 75 ppm. RBCs counts, haemoglobin concentration and PCV were increased significantly with the different concentrations of Profenofos, but WBCs counts and erythrocyte indices (MCV, $\mathrm{MCH}$ and $\mathrm{MCHC}$ ) were decreased significantly in rabbits with profenofos at 75 and $150 \mathrm{ppm}$.

\section{REFERANCES}

Abd Allah, A.G., 1998. Toxicological studies of some pesticides on white albino rats. M.Sc.Thesis. Fac. Agric. Cairo Univ. Giza.

Ahmed, E.E, H.H. Haleem and M.M. Arafa, 2002. High mortalities in poultry farms as a result to polluted ration. $1^{\text {st }}$ Conf. Central Agric. Pesticide Lab., 3-5 Sep., Giza, Egypt.

Ayyat, M.S., U.M. Abd-El Monem, H.M. El-Gendy and H.M. El-Fateh, 2000. Profenofos effects on rabbit performance and their amelioration by using natural clay. World Rabbit Science, 8:4, 169-175.

Bartholomew, R.J and A.M. Delaney, 1964. Proc. Australian Assoc. Clin. Biochemistry. 1:64.

Britton, K.E., V. Quinn, B.L. Brown and R.P. Ekins, 1975. A strategy for thyroid function tests. British Med. J., 3: 350-352.

Choudharry, N. and S.C. Joshi, 2002. Reproductive toxicity of endosulfan in male albino rats. Bull. Enviro. Contam. Toxicol., 70: 285-289.

El-Halwagy, M.S., 2000. Protective effects of vitamin C and zinc on organophosphorus insecticide toxicity in albino rats. Ph.D. Thesis, Fac. Of science, Cairo university, Giza. 
El- Kashoury, A. A.,1999. Sub-chronic toxicity studies of imidaclopride, Profenofos and carbosulphan and their mixture on albino rats. Ph.D. Thesis, in Agricultural Sciences Faculty of Agriculture, Cairo University.

El-Said, M.M., 1997. Eco-toxicological behavior of some pesticide with special references to haemogram and calcium metabolism in laboratory animals. Ph.D.Thesis, Inst. Of environment. Studies and Research. Ain Shams Univ.

Empfehlungen, 1972. Der deutschen Gesellschaft für Klinische Chemie. Z. Klin. Chem. U. Klin. Biochem., 10:182. cited by Farid,MM (1997).

Farid, M.M., 1997. Environmental hazardous of agrochemicals in albino rats. Ph. D. Thesis. Inst. of Environ. Studies and Research, Ain Shams Univ.

Faulkner, W. R. and J.W. King, 1976. In Funda-mentals of clinical chemistry. $2^{\text {nd }}$ Ed., Saunders, Philadelphia.

Gupta, R.C., 1994. Carbofuran toxicity. Journal of Toxicology and Environmental Health, 43(4): 383-390

Hashem, A., 1980. A study of the mode of action of paraquat in isolated perfused rat liver and its influencing by means of an SOD. Active $\mathrm{Cu}-\mathrm{Complex}(\mathrm{Cu} \mathrm{L}$ tyr). Thesis. Tierarztliche Fakultat Ludwing Moximiliams University at Muchen. Cited by Jain, 1993.

Hassan, Y.M., Z.H. Zidan, Y.A. Abd- El-Daim and I.S. Ashoush, 2002. Effect of fenitrothion and cadmium xenobiotics on some biological systems in male rabbits as indicated to Human nutrition practices. $1^{\text {st }}$ conf. of the Central Agric. Pesticide Lab., 3-5 Sep., Giza, Egypt.

Henry, R.J, D.C. Cannon and J.W. Winkelman, 1974. Clinical chemistry. Principles and Techniques. Harper and Row, Publ., P.415.

Hotz, K.J., A.G.E. Wilson, D.C. Thake, M.V. Roloff, C.C. Capen, J.M. Kronenberg and D.W. Brewster, 1997. Mechanism of thiazopyr induced effects of thyroid hormone homeostasis in male Sprague-Dawley rats. Toxicol. \& Appl. Pharmacol., 142 (1): 133-142.

Jain, N.C.,1993. Evaluation of animals and polycythemia. In: Jain, N.C.(ed.). Essential of veterinary hematology. pp:133-159, Lee \& flebiger, philadelphia

Maryam, A., A. Mohammad, K. Abbas, H. Ruhollah and S. Omid, 2003. Biochemical evidence for free radical induced lipid peroxidation as a mechanism for subchronic toxicity of malathion in blood and liver of rats. Human and Experimental toxicology., 22(4) 205-211.

Marx, J.M., 1996. Toxicology of the blood pathophisiology, Toxicology pathology and mechanistic. In: Niesink, R.J .M.; Deviries, J. and Hollinger, H.M.A. (eds) Toxicology principles and applications, pp: 817- 839 .CRC Press. BCCA Raten. London .New York.

Patton, C.J and S.R. Crouch, 1977. Determination of urea. Anal. chem., 49:464

Rahman, M.F and M.K. Siddiqui, 2003. Bio-chemical enzyme activity in different tissues of rats exposed to a novel phosphorothionate. J. Environ. Sci. Health. B., 38(1): 59-71.

Reitman, S. and S. Frankel, 1957. Acolorimetric method of the determination of serum glutamic oxaloacetic and glutamic pyruvic transaminases. Am. J. Clin. Path., 28: 57-63.

Salem, H.A., K.A. Al-Busadah, Y.A. Hussein, and H.A. Amer, 1999. Effect of supracide and sharkesuper administration on thyroid, gonadotropic and female sex hormones in rabbits. Pakistan Vet. J., 19(4): 188-191. 
Schalm, O.W., 1986. Veterinary Hematology $4^{\text {th }}$ Ed., Lea and Febiger, Philadelphia, PP.21-86.

Siest, G, J. Henny and F.P. Schiele, 1981. Cholestrol variation biologics et values de references interpretation Des examines de laboratory, Karger ed., P. 135-150. (Cited by Zidan et al. 1998).

Snedecor, G.W. and G.W. Cochram, 1980. Statistical method. $6^{\text {th }}$ Ed. The Iowa state university. Press Ames, USA.

Waber, H., 1966. Cholinesterase Kinetic colorimetric method. Dtsch. Med. Wschr., 91: 1927.

Wills, E. D., 1985. Biochemical diagnosis "Bio-chemical Basis of medicine", Wright, Bristol, England, P 489-499.

Zayed, S.M., M. Farghaly and S. El-Maghraby, 2003. Fate of ${ }^{14} \mathrm{C}$ chlorpyrifos in stored soybeans and its toxicological potential to mice. Food chem. Toxicol., 41 (6): 767-772.

Zidan, Z.H., A.K. Mashhour, A.A. Zidan, A.A. Fawzy and Y.A. Okasha, 1998. Toxicological effects of long term administration of minimal doses of certain insecticides on white albino rats. Proceeding, seventh conferences of Agri. Devel. Rese., Cairo, Egypt. 3: 1085-1101. 
الإستجابات الفسيولوجية فى الارانب النيوزلندى نتيجة شرب ماء ملوث بمادة

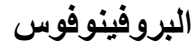

سالم محمد سالم إبراهيم، محمد إبراهيم القبيبصى 2

1- قسم الإنتاج الحيوانى، كلية الزراعة، جامعة القاهرة، الجيزة، مصر، 2- ق قسم الكيمياء الحيوية، كلية الزراعة، جامعة القاهرة، الجيزة، مصر الزئرة

أجري البحث فى كلية الزر اعة جامعة القاهرة بالجيزة علي ثلاثين ذكر أرانب من نوع النيوزلندى للتنعرف

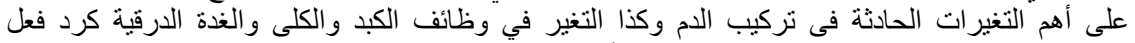

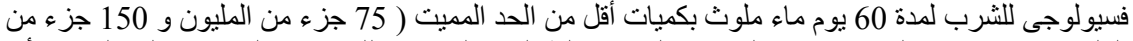

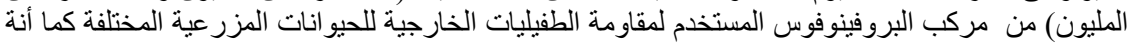

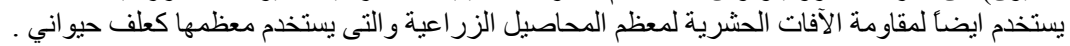

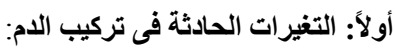

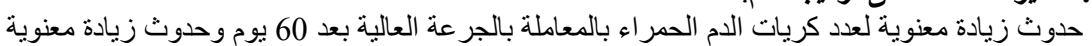

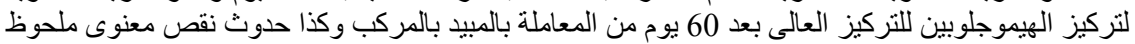

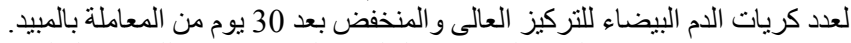

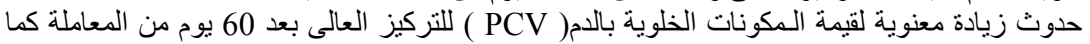

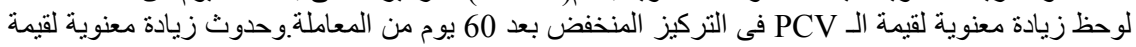

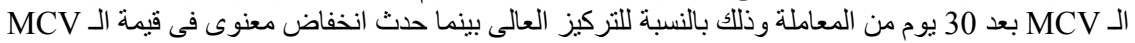

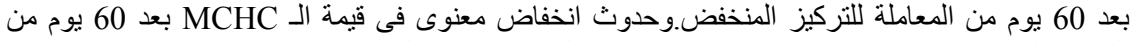

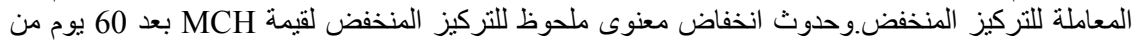

المعاملة.

ثانياً: القياسات الفسيولوجية التي تستخدم كليل علي حدوث التغيرات في وظائف الكبا ويمكن إيجازهـا فيما يلي:

1)حدوث نقص معنوي في نثــاط إنزيم الـ ALT بعد 30يوما" من المعاملة بينما حدث زيادة معنوية ملحوظة

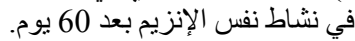

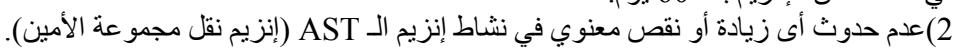

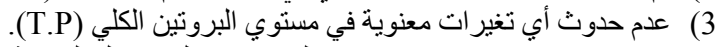

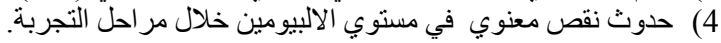

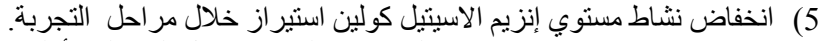

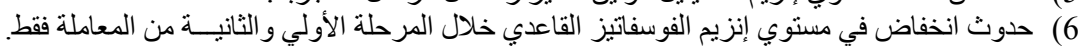
7) عدم حدوث أي اختلافات معنوية فى مستوي الكولنترول خلال مر احل التجربة المختلفة.

ثالثًا: حيث حدث نقص معنوي في مستوي اليوريا و الكرياتينين كليل علي حدوث التغيرات في وظائف الكلى. 
رابعاً: التغيرات في وظائف الدرقية حيث:

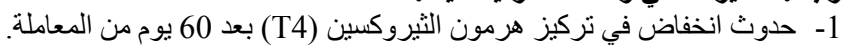

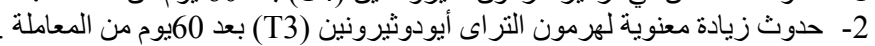

